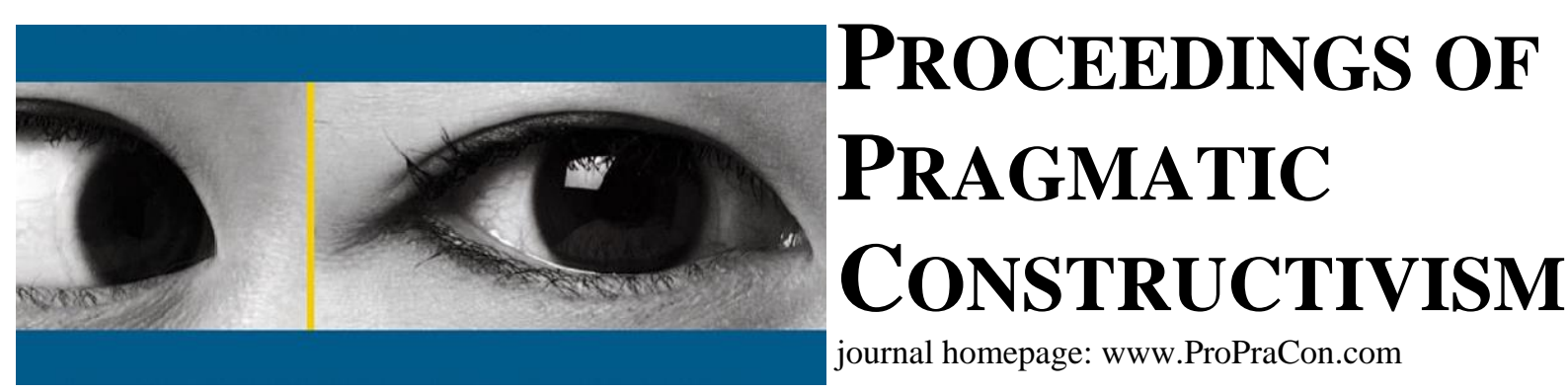

\title{
The role of stakeholders in relation to the business model in the taxi industry
}

\author{
Jakob Bitsch \\ Aarhus University; School of Business and Social Sciences; Department of Management \\ Bartholins Allé 10; 8000 Aarhus C; Denmark \\ Sara Brochstedt \\ Aarhus University; School of Business and Social Sciences; Department of Management \\ Bartholins Allé 10; 8000 Aarhus C; Denmark \\ Alexander Hjerrild Holm \\ Aarhus University; School of Business and Social Sciences; Department of Management \\ Bartholins Allé 10; 8000 Aarhus C; Denmark \\ Andreas Knudsen \\ Aarhus University; School of Business and Social Sciences; Department of Management \\ Bartholins Allé 10; 8000 Aarhus C; Denmark
}

\begin{abstract}
This paper illustrates how business models and business model innovation are related to the theory of stakeholders. The paper explores how lack of business model innovation in the taxi industry, can be explained by the relation to the power and interests of its stakeholders. The authors have employed an explanatory case study, using multiple sources of evidence, primarily archival records and observations. The research reveals that the business model of the taxi industry have not experienced major changes, even though the environment surrounding the taxi industry have seen several changes. An analysis of the stakeholders of the taxi industry explains that the lack of business model innovation is a consequence of the misfit between the power of the taxi industry and government, and the customers. The paper contributes to the existing literature of business models, business model innovation and stakeholder theory, and their relation in between.
\end{abstract}

Keywords: Pragmatic constructivism; Business Model; Business Model Innovation; Stakeholder Theory; Taxi industry.

\section{Introduction}

In recent years, the topic of business models has gained a lot in popularity (Schneider \& Spieth, 2013; Zott, Amit, \& Massa, 2011). There seem to be a popular notion that creating the right business model is essential to a firm (Magretta, 2002; Zott \& Amit, 2010). It is no longer just an option to compete on products and services but through the business model settings as well, as these are harder to copy (Amit \& Zott, 2012; Casadesus-Masanell \& Zhu, 2010; Chesbrough, 2010; D. Mitchell \& Coles, 2003) Business models have to be able to create as much value as possible from the resources and capabilities of the business. In order for a company to be able to continuously gain as much value from its business as possible, a need to change the business model can occur, when the situation of the company changes (Casadesus-Masanell \& Ricart, 2010; Chesbrough, 2010; Demil \& Lecocq, 2010; Schneider \& Spieth, 2013). Change in external factors such as changing competition, new technology or shifting customer preferences may lead to a need for change in the business model in order to provide new opportunities to compete or create customer value (CasadesusMasanell \& Ricart, 2010; Chesbrough, 2010; Demil \& Lecocq, 2010; Schneider \& Spieth, 2013). 
From that perspective, it is interesting to observe the taxi industry, where the business model does not seems to have had any big changes for many years, and it seems like every company in the industry is having similar business models. In continuation, it is interesting to compare the gridlock situation of the taxi industry to that of the airline industry. The airline industry has been in the same situation as the taxi industry, but has now seen tremendous changes over the last decades (Casadesus-Masanell \& Ricart, 2010; Transportministeriet, 2013). The competition in the airline industry is strong, and the players in the market are competing on many different parameters, such as price and quality, with many different elements in their business models.

This kind of competition does not exist in the taxi industry. Almost all taxis provide the same homogeneous service, where consumers do not have the opportunity to choose between different standards (Konkurrencestyrelsen, 2008). This situation exists in spite there have been changes in the environment surrounding the taxi industry. New technology has been developed and there could be changes in customer preferences. Another external factor to take into consideration is change in competition, where other means of transportation plays a major role. A report made by Konkurrencestyrelsen (2008) shows that one in three costumers would take a taxi more often, if there was a $15 \%$ decrease in prices and the taxi was less luxurious. It is therefore puzzling why the business model of the taxi industry has not changed in order to better serve the needs of the customers, and why there does not seem to have been changes in the business model of the taxi industry to accommodate changes in the environment.

The aim of this paper is to investigate, from a stakeholder perspective, why there have been no major changes in the business model of the taxi industry. We will investigate if the balance between the different stakeholders in the taxi industry can possibly explain the lack of changes in the business model. In order to understand the lack of competition in the industry, the thoughts of Casadesus-Masanell \& Ricart (2010) will be applied. Furthermore, the framework of Casadesus-Masanell \& Ricart (2010) will be used to explain the extant business model of the industry, and which tactical options this leaves for competition.

The remainder of the paper is structured as follows: In section two, the theoretical backgrounds of business model, business model innovation and stakeholder theory are presented. The third section discuss the method used in this paper. Section four presents our findings. In section five findings and contributions of this paper are discussed and future research areas are suggested.

\section{Business model theory}

In their examination of the literature on business models, Zott et al. (2011) reveal that the definitions of business models differ substantially, and that researchers and practitioners have not yet developed a common definition in order to make them capable of drawing effectively on the work of others. In the literature, numerous definitions of business models exist, and as a research area, business models are still relatively poorly understood (e.g. (Casadesus-Masanell \& Ricart, 2010; Chesbrough \& Rosenbloom, 2002; Magretta, 2002; Osterwalder, Pigneur, \& Tucci, 2005). Magretta (2002) suggests two critical tests; the narrative test and the numbers test, and thus emphasizes that the "story of the business model has to make sense" and "the P\&L has to add up”. Chesbrough \& Rosenbloom (2002) focus on capturing value from technology and innovation and argue that there is a need to understand the cognitive role of the business model. Furthermore, the business model can be seen as the blueprint of how a company does business - a conceptual model based on strategic issues which states how the business functions (Osterwalder et al., 2005).

The present paper will use the notion of Casadesus-Masanell \& Ricart (2010) and their integrative framework to distinguish and relate the three concepts: strategy, business models and tactics. They introduce a generic two-stage competitive process framework, where firms choose their business model in the first stage and make tactical choices in the second stage that are guided by their goals. This framework is chosen because of its ability to explain the connection between the choice of business model and the tactical choices it enables the company to fulfil. In order to define the expression "business model”, this paper is consistent with Casadesus-Masanell \& Ricart (2010) in their choice of "the logic of the firm, the way it operates and how it creates value for its stakeholders”, which is a definition captured by Fuller, MacMillan, Demil and Lecocq. With this definition as the starting point, Casadesus-Masanell \& Ricart (2010) ask the question: what parts are business models made off? They argue that these parts are made of 1 . the concrete choices made by management about how the organization must operate, and 2. the consequences of these choices. These are distinguished into three types of choices: Policies, assets and governance structures. This paper will use these three types to analyse the business model of the taxi industry and afterwards use the two-stage framework to explain the connection between the business model of the industry and its choices of tactics. 


\subsection{Business model innovation}

Even a well-established and currently successful business model cannot be understood as a permanent given because of the effect from environmental dynamics (Chesbrough, 2010; Demil \& Lecocq, 2010; Schneider \& Spieth, 2013). Therefore, it can be important to be able to make business model innovation before forced by circumstances (Schneider \& Spieth, 2013; Zott \& Amit, 2010).

As with research on business models, research on business model innovation seems to lack a common definition (Schneider \& Spieth 2013). Consequently, the research are often done in silos with different reasons, purpose and definition for business model innovation. Zott \& Amit (2010) define business model innovation as the process of designing new or modifying the firm's extant activity system, whereas Carayannis et al. (2015), on a broader level, define it as a revolution or evolution of a current business model. If an aspect of the extant business model changes, it can be considered business model innovation. When applying the framework from Casadesus-Masanell \& Ricart (2010), it can therefore be considered business model innovation if some of the choices and consequences, that define the business model, changes.

The reasons for engaging in business model innovation can be many. Some of the reasons extracted from literature are change in the environment (Demil \& Lecocq, 2010), new technological opportunities (Chesbrough, 2010), cost reduction and flexibility (Carayannis et al., 2015) and new opportunities for competing (Casadesus-Masanell \& Zhu, 2010; Casadesus-Masanell \& Ricart, 2010; D. Mitchell \& Coles, 2003). Johnson et al. (2008) identify five strategic circumstances where there can be a need for business model innovations: 1) the opportunity to serve a large group of potential customers that are currently out of the market. 2) The opportunity to capitalize on a new technology with a new business model. 3) The opportunity to get a job done for the customer in a more effective manner. 4) The need to fend of low-end distributors. 5) The need to respond to a shifting base of competition. If any of these strategic circumstances are present, there can be an opportunity to gain from business model innovation (Johnson et al., 2008).

We argue that every one of these reasons can be transferred to the framework of Casadesus-Masanell \& Ricart (2010), if the only possibility to deal with these circumstances is to change the business model in order to gain new tactical options.

\subsection{Stakeholder theory}

For decades, academic writers have argued that stakeholders and stakeholder management are important aspects of a firm's ability to succeed with their strategy (Ackermann \& Eden, 2011; Bryson, 2004). However, these writers have had a hard time coming to an agreement of how to define stakeholders. An early definition was given by Stanford Research Institute (1963; quoted in Freeman, 1984), who define stakeholders as "those groups without whose support the organisation would cease to exist”. This definition was later refined by Freeman (1984) to not only consider who can affect, but also those individuals or groups who are affected by, the organisation. Strategic stakeholder theory has brought about three streams of research, trying to answer three different questions (Frooman, 1999). The first stream seeks to help organisations analyse who their stakeholders are. A second stream aims at explaining the stakeholders' interests, while the third stream of research attempts to explain how stakeholders seek influence.

With respect to the question of who the stakeholders to an organisation are, the definition of a stakeholder naturally leads to a very extensive list of stakeholders for most organisations. Consequently, it might be beneficial to use a framework to identify an organisation's major stakeholders. Such a framework is presented in Mitchell et al. (1997). Mitchell et al. (1997) argue that for an actor to be denoted as a major stakeholder, it requires the presence of three elements: power, defined as "the ability of the power holder to bring about desired outcomes despite resistance from other actors"; legitimacy, defined as "a generalized perception or assumption that the actions of an entity are desirable, proper, or appropriate within some socially constructed system of norms, values, beliefs, and definitions"; and urgency defined as “calling for immediate attention”. Mitchell et al. (1997) further argue that urgency requires the presence of at least one of time sensitivity and/or criticality of the claim or relationship to the stakeholder. This means that organisations must prioritise the wants and needs of the stakeholders who have the most power, since these are the ones who can make or break the purpose of the organisation. Another important aspect to consider is the amount of risk at stake for the stakeholder, which will correlate with the degree of interest held in the organisation (Ackermann \& Eden, 2011).

Together, the aspects of power and risk form the axes of the power/interest grid as seen in figure 1, which manages to take both the question of who the stakeholders are, as well as what their interests are, into account (Ackermann \& Eden, 2011). This framework is designed to help managers decide which stakeholders to address when implementing strategic decisions. Stakeholders in the "crowd" should be seen as potential, rather than actual 
stakeholders, and management should not devote much attention to this group (Ackermann \& Eden, 2011). The "context-setters" have power to influence the future overall context of the organisation. However, until the interest in the organisation is increased, this group should be seen as potential rather than actual stakeholders (Ackermann \& Eden, 2011). The "subjects" can have either a positive or a negative interest in the organisation, which will influence how the organisation should deal with them. The "players" are the significant stakeholders of the organisation, and their interests must be taken into account by the organisation in order to achieve strategic success.

Figure 1: Power/interest Grid, adopted from Ackermann \& Eden, 2011

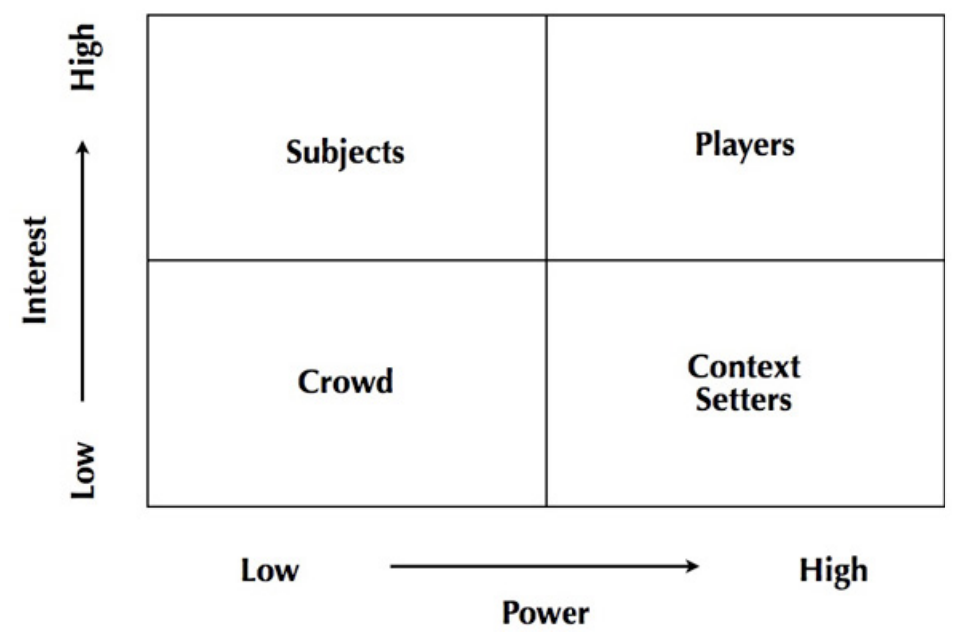

The question of how stakeholders seek influence over organisations is addressed by Frooman (1999), who shows that stakeholders can practice influence strategies in several ways. First, Frooman distinguishes between usage and withholding strategies. Usage strategies are defined as those, where the stakeholder continuesi to provide a certain resource to the organisation, but with certain demands to be fulfilled by the organisation. Withholding strategies, on the other hand, are those where the stakeholder rejects to provide a certain resource in an attempt to force the organisation to change their behaviour (Frooman, 1999). Both of these influence strategies can be done both directly, meaning by the stakeholder itself, and indirectly, meaning through allies. In combination, this leads to four different influence strategies for stakeholders; Direct usage, indirect usage, direct withdrawal and indirect withdrawal. Whether a stakeholder should adopt one or the other strategy depends on the relationship between it and the organisation (Frooman, 1999). If the stakeholder and the organisation have a low interdependence, the indirect withholding strategy will be the most effective, whereas the direct usage strategy is recommended if the parties have a high interdependence. If the organisation is dependent on the stakeholder, but not the other way around, the stakeholder will hold the power-position and the direct withholding strategy is recommended. If, however, the stakeholder is dependent on the organisation, but the organisation can manage without the stakeholder, the organisation is holding the power-position and the indirect usage method is recommended (Frooman, 1999). For a sum-up of the four strategies and when to use them, see figure 2.

Figure 2: Frooman's influence strategies, adopted from Frooman, 1999

\begin{tabular}{|c|c|c|c|}
\hline \multirow{3}{*}{ 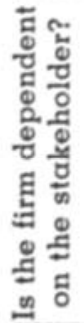 } & \multirow{3}{*}{$\begin{array}{l}\text { No } \\
\text { Yes }\end{array}$} & \multicolumn{2}{|c|}{ Is the stakeholder dependent on the firm? } \\
\hline & & $\begin{array}{c}\text { No } \\
\text { Indirect/withholding } \\
\text { (low interdependence) }\end{array}$ & $\begin{array}{c}\text { Yes } \\
\text { Indirect/usage } \\
\text { (firm power) }\end{array}$ \\
\hline & & $\begin{array}{l}\text { Direct/withholding } \\
\text { (stakeholder power) }\end{array}$ & $\begin{array}{l}\text { Direct/usage (high } \\
\text { interdependence) }\end{array}$ \\
\hline
\end{tabular}




\section{Methodology}

\subsection{Research method}

This study was conducted as an explanatory case study in the attempt to answer the question of why there has been a lack of business model innovation in the Danish taxi industry. The study was limited to a focus on the traditional taxi business of transporting private customers from A to B. A deductive approach was taken by applying the theory of business models presented by Casadesus-Masanell \& Ricart (2010) and the stakeholder theories presented by Ackermann \& Eden (2011) as well as Frooman (1999) to analyse and interpret the data collected (Ryan, Scapens, \& Theobald, 2002; Yin, 2009). Case studies have experienced an increase in popularity within management accounting research during the last decades, because they enable researchers and practitioners to explain the underlying reasons for the topic in question (Dalby et al., 2014; Friis et al., 2015; Haubro et al., 2015; Larsen et al., 2014; Lueg et al., 2016; Lueg et al., 2015; Lueg et al., 2014; Lueg et al., 2013; Malmmose et al., 2014). This was exactly the aim of this study, which is why a case study was deemed the optimal way to find a solution to the research question of this study.

In this paper, pragmatic constructivism is used as a paradigm for knowledge creation. The paradigm is not used directly as a tool of analysis but as an important tool in order to collect and interpret data. Pragmatic constructivism is assisting the understanding of how different actors, in interaction, creates the reality of the taxi industry. The reality exists independent of the world, and consist of facts, possibilities, values and communication (Nørreklit et al., 2006; Jakobsen et al., 2011). Each actor has their own topos and only through communicating the facts, values and beliefs can they get an integrated reality and reach a common topos.

\subsection{Data collection}

Data have been collected by the means of archival documents as well as observations of how the actors in the industry do business. The archival documents used in this study are all publicly available to everyone having interest in the topic. When analysing an entire industry it is, naturally, of huge importance to consider all possible angles of a problem. To achieve this, archival documents have been drawn from Dansk Taxa Råd, which represents the interests of the taxi companies and drivers, Konkurrencestyrelsen and Forbrugerrådet, who represent the interests of the customers, and The Ministry of Transportation, who can be seen as a neutral player in this industry. By including all three perspectives in the analysis, it can be argued that the three major interests in the taxi industry are covered. This is important, since the different players in the industry all have different topos. Therefore, it is of high importance to include their view to reach a better understanding of the facts, values and beliefs characterising the industry. Furthermore, observations of how the taxi companies act in their environment have been made in the attempt to exemplify the consequences of how the industry has developed through the years.

\subsection{Limitations}

This qualitative approach to studying the Danish taxi industry certainly has its limitations. First, qualitative studies are very sensitive to subjective interpretations of the gathered data (Ryan et al., 2002; Scapens, 1990; Yin, 2009). This is also, and maybe to an even higher degree than usual, the case in this study, since the analysis will be based on subjective understanding and interpretation of the data without the use of for example interviews to get the interpretations confirmed. However, applying data with different perspectives, and thereby getting a more nuanced picture of the situation addressed this subjectivity. A second limitation is the lack of validity characterising case studies (Ryan et al., 2002; Yin, 2009). The external validity of this particular study is rather limited, since a lot depends on the way the industry is situated in Denmark and affected by Danish legislation, which makes it hard to generalise to other contexts. The internal validity of the study has been addressed through applying multiple data sources and sampling methods, which secures an increase of the internal validity. Construct validity was secured by using well-established theoretical concepts to perform the analysis (Ryan et al., 2002; Yin, 2009).

\section{Business model in the taxi industry}

The taxi industry is, together with other means of transportation (plain, busses, trains, ferries), a part of commercial passenger transportation. The main purpose of commercial passenger transportation is to provide transport services for a payment. In 2013, the taxi industry in Denmark accounted for 2.800 individual businesses that together had a yearly turnover of approximately 5 billion DKK. In 2010, the taxi industry accounted for $22 \%$ of the total revenue within all commercial passenger transportation in Denmark (Transportministeriet, 2013). The Danish taxi industry is a central part 
of the Danish infrastructure and public transportation. The industry works as an independent means of transportation and as an extension to other means of transportation (Dansk Taxi Råd, 2010).

As stated, we will use the notion from Casadesus-Masanell \& Ricart (2010) to analyse the business model of the taxi industry, in order to explain the connection between the extant business model in the industry and the tactical choices this gives the companies for competing in the industry. The reason for this is that the business model applied determines the tactical possibilities for the companies. In Casadesus-Masanell \& Ricart's (2010) framework, business models consist of choices and consequences. The choices consist of policy choices, asset choices and governance choices. These choices have consequences. The analysis of the business model will be an analysis of the dominant business model in the industry, as it seems like every company in the industry follows a similar business model. Casadesus-Masanell \& Ricart (2010) argue that it can be difficult to analyse all the small aspects of a business model, why they suggest it to be done at an aggregated level. This approach is applied in this paper.

Policy choices refer to the course of action a firm adopts to its way of doing business (Casadesus-Masanell \& Ricart, 2010). In the taxi industry, the business model is highly dominated by policy choices, and policy choices are thereby an important aspect. One policy choice in the industry is that all the companies in the industry are privately owned. Another choice is that every firm focus on solidarity. There is a common understanding among the taxi drivers to not steal customers from each other. Consequently, there is a natural queuing system at pickup places, where the taxis form a line and wait their turn (Konkurrencestyrelsen, 2008). It is frowned upon if a taxi company breaks the rules and norms in the industry, and it is common that other companies in the industry steams together to stop this behaviour (Andersen, 2014). Taxi licences are geographically limited, which means that taxi drivers only can be allowed to drive outside the area from where their license is issued under specific circumstances. Another policy choice is the methods available for getting a taxi. There seems to be two common ways of doing this. The first is to call a booking office that will send a taxi. The second is to go to a taxi parking area. Not many customers get a taxi from the streets. The taxi companies are registered at a booking office, who distributes customers evenly between the drivers who use the same booking office (Konkurrencestyrelsen, 2008). A last important policy choice is that taxies should drive with all customers. Taxi drivers are not allowed to refuse to serve customers, in hope of getting a more profitable customer later.

A consequence of the ownership structure is that companies have no opportunity to expand their business and thereby take advantage of efficiency of scale. Because the customers are distributed evenly between drivers, the customers do not have a say in what taxi to get. A consequence of this policy choice is that every company in the industry is forced to provide the customers with the same homogeneous service for the same price. The taxi companies get their share of the customers, no matter how well they perform. There is no competition and this leads to the consequence that every company in the taxi industry is charging the customers with maximum tariffs. The consequence of the taxi drivers only being allowed to operate within a restricted area is that they have a limited customer pool. This is furthermore limiting the taxi companies' ability to compete.

Asset choices refer to the assets a company employs in order to get their job done (Casadesus-Masanell \& Ricart, 2010). In the taxi industry, the main asset for the taxi companies is the car they use to perform their service. The cars are often expensive and of high quality and there is no differentiation among the cars. During the last couple of years, the society have had a greater focus on climate changes, which have forced the taxi industry to provide cars that live up to more climate friendly standards (Transportministeriet, 2013), which might have made a minor change in the choice of assets. The consequence of using expensive cars is that the customers expect a high quality product whenever they take a taxi. Another consequence of the expensive cars is higher prices for the customers.

Governance choices refer to how companies structure their contractual agreements that confer decision rights over policies and assets (Casadesus-Masanell \& Ricart, 2010). In the taxi industry, the companies have an agreement to join a booking office. A part of the agreement between the booking offices and the taxi companies is that the name and telephone number of the booking office must be represented on all the taxies that belong to the booking office. In the eyes of the consumers, the booking office is thereby often seen as the overall company (Konkurrencestyrelsen, 2008). Other agreements between the two parties are that the booking office control the prices on the taximeter and the taxis have to live up to a certain standard for the booking office. The booking offices have the authority to punish the taxi companies if they break the agreements (Konkurrencestyrelsen, 2008). The consequence of using booking offices is that the taxi companies cannot function as an independent actor in the market. The individual companies have to set the same price and quality as all the other companies controlled by the booking office. 
Table 1: Taxi company business model - choices and consequences

\begin{tabular}{llll}
\hline Choices & & Consequences \\
\hline Solidarity & $->$ & Low competition on price, quality and service \\
Privately owned company & $->$ & Small company \\
Only operate in own geographical area & $->$ & Limited customer pool \\
Pickup mainly from pickup areas & $->$ & Even distribution of customers \\
Use of booking offices & $->$ & Even distribution of customers \\
& & Standard booking office prices (maximum tariff) \\
Accept every order & $->$ & Servicing all customers \\
Expensive Cars & $->$ & Higher costs, higher customer experience
\end{tabular}

A summary of the choices and consequences that define the business model are presented in Table 1 . Consequences of the business model in the taxi industry are low competition, maximum prices and a homogeneous service level within the industry. The overall consequence of the existing business model is that it leaves almost no ability to compete. The business model of the taxi industry has only undergone minor changes and the business model is approximately the same as it was decades ago. There have been no major changes that opened up new possibilities for competing in the market.

\subsection{Business model innovation in the taxi industry}

Referring to Johnson et al. (2008) and their five strategic circumstances, which can lead to business model innovation, there seem to have been several changes in the environment surrounding the taxi industry. Consequently, this section will elaborate on these changes, which according to the theory of business model innovation should have led to changes in the business models of the taxi industry.

In the report of Konkurrencestyrelsen (2008), it is stated how 33\% of the customer would use taxis more often if the price was lowered by $15 \%$ and was less luxurious. Furthermore, Nielsen \& Petersen (2010) also report that $40 \%$ of the customers would use taxis more often if the prices were decreased by $10-20 \%$ and the taxi was less luxurious. The theory of business model innovation states that this is a situation, which could lead to changes in business models since this serves an opportunity to service customers who are currently out of the market (Demil \& Lecocq, 2010; Johnson et al., 2008).

The immense technological evolution, which has happened within the last decades, and is still happening every day, is leading to situations that call for changes in business models as well. Innovating the business model in accordance with the technological development is essential in order to gain as much value as possible from the new technology (Chesbrough \& Rosenbloom, 2002). To illustrate this point, the airline industry functions as a good example. The airline industry, and especially the business models of the airline industry, has gone through tremendous changes in the last decades, partly due to the development of new technology. As an example, it is no longer necessary to show up in person at the travel agency to order tickets. It can be done at home, using the PC and algorithms to calculate the cheapest flights, shortest, fewest stops etc. As a consequence, the business models of the companies in the airline industry have evolved and have become more diverse, which have led to many new travel opportunities for the customers, new products and lower prices (Casadesus-Masanell \& Ricart, 2010; Transportministeriet, 2013). This kind of innovation of business models has not to the same extent taken place in the taxi industry.

Technological developments and price preferences are just a few examples of changes in the environment of the taxi industry, which expectedly could have led to changes and innovations in the business model of the taxi industry. In a general perspective as well, it is puzzling that the business model of the taxi industry has seen so relatively few changes when surrounded by a world in constant change and evolvement. 


\subsection{Limited tactical options in the taxi industry}

Using the generic two-stage competitive process framework of Casadesus-Masanell \& Ricart (2010), this section will attempt to explain the connection between the strategy, business model and tactical options in the taxi industry, in order to contribute to the understanding of the lack of changes in the business model of the taxi industry. Figure 3 presents the framework:

Figure 3: The generic two-stage competitive process framework, adopted from Casadesus-Masanell \& Ricart 2010

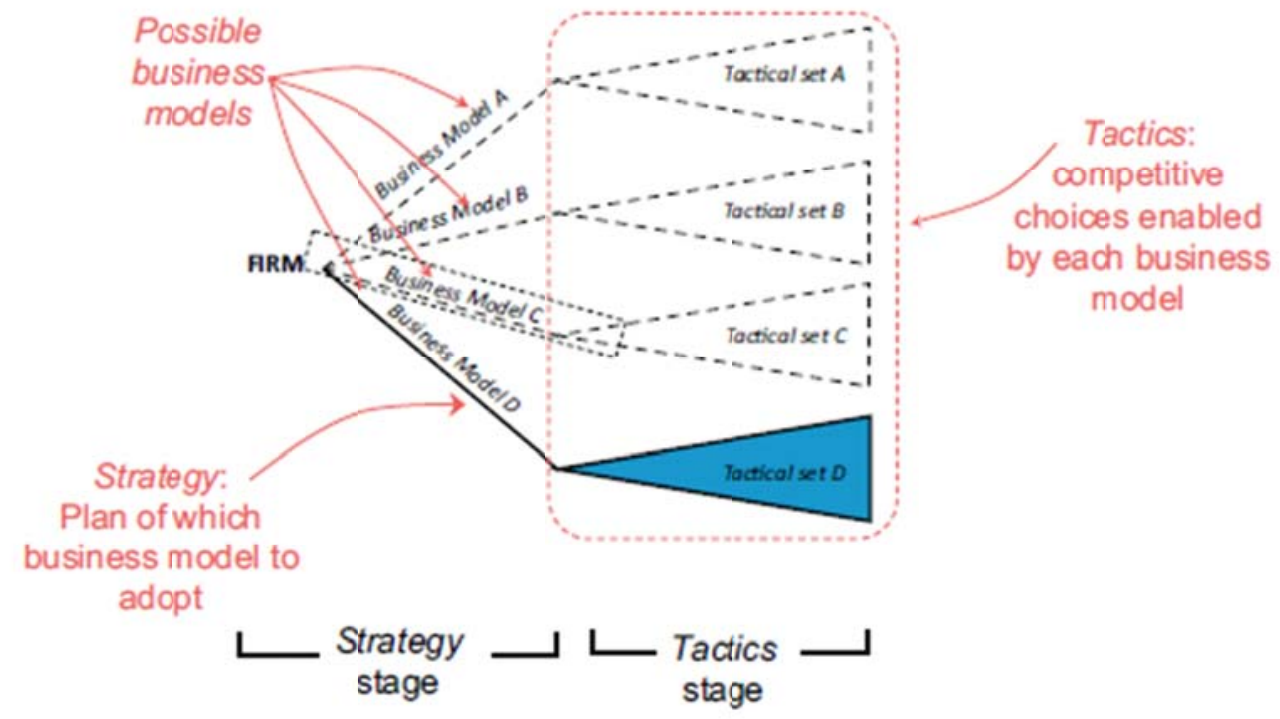

As described by Casadesus-Masanell \& Ricart (2010), and as illustrated in the framework, a company has certain tactical competitive choices as a consequence of the business model chosen, which again is chosen in coherence with the strategy of the company. Therefore, if a company wish to change the scope of their tactical possibilities, they have to change their business model (Casadesus-Masanell \& Ricart, 2010).

In the taxi industry, all the companies have the same business model and therefore compete on a very narrow set of tactical choices. None of the companies are able to take advantage of the changes in the environment surrounding the taxi industry, because their business model is limiting their tactical choices. It would be expected that some of the companies in the taxi industry would have changed their strategy and business model in order to gain new tactical competitive choices, which could take advantage of the changes in the environment and thereby separate themselves from their competitors. However, none of the companies have changed their strategy and business model, but continues to compete in the same narrow set of tactical choices.

\section{Stakeholders in the taxi industry}

The reason for introducing stakeholder theory to the analysis of the Danish taxi industry is the theory's possible ability to explain the existing business model of the taxi companies, and why they do not utilise the potential of the external environment to innovate their business model. To provide an explanation for the lack of business model innovation in the industry, the major stakeholders of the industry will be identified using the framework of Mitchell et al. (1997). In continuation of this, the internal power/interest relation between the stakeholders will be analysed based on the framework of Ackermann \& Eden (2011).

The definition of stakeholders provided by Freeman (1984), as "those groups or individuals who can affect or are affected by the organisation”, will naturally lead to a very extensive list of stakeholders for the taxi industry. Therefore, this analysis will only take into account the major stakeholders of the industry. Mitchell et al. (1997) argue that major stakeholders differ from other actors by having the power, legitimacy and urgency to influence the organisation. Based on these concepts, we argue that the three major stakeholders in the Danish taxi industry are the authorities, the customers and the taxi industry itself. These three major stakeholders are seen from an aggregated perspective where they are grouped based on their interest. 
The authorities compose of the government, who make all the laws, rules and regulations and the municipalities, whose job is to enforce the law and issue taxi licences according to providing the customers with an adequate supply. Because the taxi industry in Denmark is so tightly bound by rules and regulations, the authorities are found to have a high degree of power, legitimacy and urgency, making them an important stakeholder to the industry (Konkurrencestyrelsen, 2008).

Another important stakeholder is the taxi industry itself, which compose of the individual taxi companies, booking offices, trade unions like $3 F$ and lobby associations like Dansk Taxi Råd. The taxi industry is an important stakeholder because they have power to influence essential decision making in the industry. Even though the municipalities issue taxi licenses, they do it based on advice and requests from booking offices, trade associations and the taxi companies themselves. In practise, this means that it is the taxi industry itself that decide how many licenses should be issued. The taxi industry have an economic incentive to issue few licences, and they are thereby limiting the competition in the industry (Konkurrencestyrelsen, 2008).

We define the third major stakeholder in the taxi industry as customers. By the term customer we have included the consumers and government agencies like Konkurrencestyrelsen and Forbrugerrådet. In relation to Mitchell et al. (1997), consumers do not have a lot of power in the relation with the taxi companies, but because they have a lot at stake, and therefore a great interest, they are still considered stakeholders in the industry. As an extension of the consumers, Konkurrencestyrelsen work for the interest of the consumers by trying to influence the authorities to make regulations, which will benefit the consumers. Because they function as a union for the customers, they have an accumulated power-base, which increase their ability to influence the players in the industry. The problem is, however, as with the individual consumers, that the industry is so tightly regulated that the power in relation to the taxi companies, although accumulated, is relatively limited. When ordering a taxi, there is no transparency for the consumers. Consumers receive a standardised service and they have no bargaining power in terms of price and quality. Furthermore, consumers have limited choices when it comes to the use of substitute transportation services, and this provides the consumers with a limited power.

\subsection{Power and interest of stakeholders}

When applying Ackermann and Eden's framework as seen in Figure 1, we look at who the stakeholders are and their interest and power in relation to the taxi industry.

The authorities have a high degree of both power and interest, and they are thereby seen as players in Ackermann and Eden's power/interest grid. Their interest lies in the taxi industry acting as an extended, and more flexible, part of the public transportation network (Transportministeriet, 2013). The authorities demand security of sufficient supply to all citizens at all times as well as transparency in prices and services (Transportministeriet, 2013). Furthermore, the authorities have an interest in the safety of the consumers and the taxi drivers. These interests are regarded as the most important reasons for the industry being so tightly regulated (Transportministeriet, 2013). Because of these regulations, the authorities must also be regarded as having a high degree of power in the industry. However, it could be argued that this power is used only to the extent necessary to secure the fulfilment of the authorities' interests. The authorities are determining how many taxi licenses are given in each municipality. They do this, however, on the basis of data provided by the taxi firms serving in the municipality, making them vulnerable to the taxi firms providing information in ways that serve their own interests, which empower the taxi industry. In sum, we argue that the authorities should be seen as "players” in the power/interest grid.

The customers, on the other hand, are categorized as "subjects" of the industry, since they have a high degree of interest, but a low degree of power. We argue that the customers cannot get a similar service from any substitutive means of transportation. In addition, the limited freedom of choice when it comes to picking a taxi decreases the power of the customer (Konkurrencestyrelsen, 2008). In a report from Konkurrencestyrelsen (2008), it is concluded that 33\% of the study-population would make greater use of taxis if the prices were lowered by $15 \%$. This can be seen as an example of the customers not having a sufficient degree of power to influence the industry, since this interest of the customers is yet to be taken into consideration.

As seen from an aggregated perspective, the taxi industry naturally have a high degree of self-interest. The power of the taxi industry is high due to the regulations provided by the authorities. The regulations are protecting the taxi companies from competition from new entrants. The solidarity characterising the industry increases the industry's power of influence because the other players will oppose any actions not in accordance with the generally accepted procedures (Andersen, 2014). Since the industry is able to influence the regulations by providing the data basis for them (Konkurrencestyrelsen, 2008), the taxi industry is considered to have both high internal- and external power. Therefore, the taxi industry should be categorized as a "player" in the power/interest grid. 
In sum, the most important actors in the taxi industry are the industry itself as well as the authorities. Both parties are categorized as "players" in the industry, and they have an interdependent relationship. The authorities provide regulations, protecting the industry, and in return, the taxi firms are required to fulfil certain demands set by the authorities. It can be argued that the authorities are the most powerful stakeholders in the taxi industry, since a major part of the power of the taxi industry is based on regulations made by the authorities.

\subsection{Stakeholder influence on the business model}

Having analysed the major stakeholders of the Danish taxi industry and their power/interest relations, this section analyses how the power and interests enables the different stakeholders to influence the dominating business model of the industry. This part of the analysis will take offset in Frooman's (1999) framework on influence strategies in combination with the previous analyses. As mentioned earlier, Frooman (1999) states that a stakeholder has four ways of influencing the firm: direct usage, indirect usage, direct withholding, and indirect withholding. As can be seen from figure 2, whether a stakeholder should make use of one strategy or the other depends on the power relation between the stakeholder and the firm.

Above, we concluded that the authorities and the taxi companies are highly interdependent. According to Frooman (1999), this will lead the authorities to practice the direct usage strategy in their attempt to influence the business model of the taxi industry. Furthermore, it was concluded that the authorities have a high degree of power they can use in to influence the taxi companies. This power is mainly practiced through rules and regulations that have a direct impact on the possible choices of business model for the companies in the taxi industry. Some of the choices made in the business model of the taxi companies are forced upon them through these rules. Every company have to use a booking office in order for the customers to have easy access and secure an acceptable service level (Transportministeriet, 2013). In addition, they have to serve all customers. Taxi companies have to be privately owned and are only allowed to do business inside the geographical area of where their license is issued. The municipalities regulate the number of licences. This secures that all areas are served sufficiently. Since many of these rules are directly influencing the competition, the authorities have stated a maximum tariff the taxi companies can charge, in attempt to protect the customers. Through these rules and regulations, the authorities are thereby imposing their interests on the taxi companies and influencing their choice of business model.

The taxi industry, as the other major stakeholder, are practicing a direct usage strategy as well (Frooman, 1999). The majority of their power stems from the rules and regulations that protect the industry, why the pressure from outside competitors or customers is limited. In addition, due to the limited growth possibilities of the individual taxi companies and the requirement of using booking offices, they do not have any power to oppose the industry. Therefore, the taxi industry is able to influence the choices of the individual company and thereby their business model. It is in the interest of the industry that all taxi companies have good opportunities to earn money, and stay profitable. Consequently, their main interest is to minimise the competition. This is primarily done in two ways. One way is that the taxi industry is using the law to minimize competition. The other is the taxi industry's focus on solidarity. Customers are evenly distributed in order for every taxi to get their "fair share”. Not only from the booking offices where it is mandatory, but also at the pickup areas. Therefore, when every company choose to be solidary and use pickup areas this is probably due to the interest of the industry. The example of Drivr (Andersen, 2014) shows that if companies choose to stay out of the community, then the actors will use their power to punish them. At the same time, if a company is not complying with the rules of their booking office, the booking offices can punish them as well.

The last stakeholder analysed in this paper is the customers. They have great interest, but due to the limited competition and the limited possibility to choose which taxi they want to use, they have a very limited amount of power. Consequently, they cannot directly influence the business model of the taxi companies. They depend on the service provided by the taxis, given that there is no perfect substitute for this service. According to Frooman (1999), the customers are left with the option of indirect usage. Some of their interests may be served by actors, such as Konkurrencestyrelsen or Forbrugerrådet, who work towards getting the authorities to accommodate the interests of the customers. The aggregated level of customers may be able to pressure the industry as well. However, as long as their power to punish the individual company is this low, they cannot directly influence their business model. 
Table 2: Stakeholders influence on the business model of the taxi industry

\begin{tabular}{llll}
\hline Stakeholder & Interest & Power/influence strategy & $\begin{array}{l}\text { Influence on business } \\
\text { model }\end{array}$ \\
\hline Authorities & $\begin{array}{l}\text { Sufficient supply of taxies } \\
\text { Service available for all citizens } \\
\text { Transparency in prices and services } \\
\text { protection of the current industry }\end{array}$ & $\begin{array}{l}\text { High power } \\
\text { Influence by direct usage }\end{array}$ & $\begin{array}{l}\text { Use of booking offices } \\
\text { Privately owned company } \\
\text { Operate in own } \\
\text { geographical area } \\
\text { Acceptance of every order }\end{array}$ \\
Taxi industry & $\begin{array}{l}\text { Protection of existing actors } \\
\text { All actors can earn a profit }\end{array}$ & $\begin{array}{l}\text { High power } \\
\text { Influence by direct usage }\end{array}$ & $\begin{array}{l}\text { Policy of solidarity } \\
\text { Use of pickup areas }\end{array}$ \\
& $\begin{array}{l}\text { High service level } \\
\text { Reasonable prices } \\
\text { Availability of services }\end{array}$ & $\begin{array}{l}\text { Low power } \\
\text { Indirect usage through } \\
\text { government }\end{array}$ & $\begin{array}{l}\text { Low influence } \\
\text { Some interest fulfilled by } \\
\text { government influence }\end{array}$ \\
\hline
\end{tabular}

Table 2 summarises how the different stakeholders influence the business model of the taxi industry through their power and interest. As shown, the authorities and the taxi industry are getting their interest fulfilled, whereas the customers must accept the influence they can have through the authorities.

As shown in the analysis, it is clear that the stakeholders are influencing many of the choices in the business model. Furthermore, it shows how their use of power puts a limit to the innovation the individual company is able to do in their business model. It is not possible to change any part of the business model that is due to rules and regulations. In order for this to happen, the authorities have to change their interest. At the same time, they cannot make changes that will go against the solidarity in the industry, as the other actors in the industry will punish this. Changes in business model that may benefit the customers are not necessarily desirable as the customers are not able to reward such changes. An example of this is Konkurrencestyrelsen's (2008) suggestion of making different price classes with different cars and services. This is not desirable for the individual taxi company, as the customers cannot choose which taxi they want because of the booking offices and the industry's solidarity at pickup areas. Companies will not be able to get more customers and will therefore only lose profit from the cheaper cars. This in turn, leads to similar prices, services and business models, as this is the only desirable business model from the taxi companies’ perspective.

This explains how the different stakeholders, through their use of the power and interest, are limiting the choices of business model, and therefore influence why the business model has not changed. For change to happen there is a need for change in the power relations or a change in the interest of one of the two major stakeholders. This concludes that stakeholders have a great influence on the possibilities of the business model in the taxi industry, which explains the limited tactical options of the taxi companies and the low competition in the industry.

\section{Discussion}

From a pragmatic constructivism perspective, the reality created by the actors in the taxi industry is beneficial for the governance and the industry, but not for the customers. The different actors may have different values or interests but only the values that rely on facts and are within the possibilities of the actors can be fulfilled (Nørreklit et al., 2006; Jakobsen et al., 2011). Each actor has a subjective topos, which, through communication has to be integrated into a common understanding of the reality of the taxi industry. The customers may have some interest based on their values, but since these are not factually possible due to the power positions and interest influence strategies of the industry and the authorities, the costumers are left unable to act on their values. The subjective topos of the customers is therefore not valid in the reality created in the industry, as the other actors of the industry do not accept it.

Our research shows, that through their power as a stakeholder, the authorities have a major influence on the business model of the taxi industry. Because of the demand the authorities enforce on the taxi industry, through rules and regulations, the taxi companies have little opportunity to change their business model. From a stakeholder perspective, we have asked, what factors can make the business model of the taxi industry change, in order to gain more competition in the industry. In order to achieve a change in the business model of the taxi industry, there need to be a 
change in either interest from one influential stakeholder or a change in power from another (Ackermann \& Eden, 2011). One possibility is for the authorities to shift interest and thereby use their direct influence to change the business model of the industry, or create options for the companies to change themselves. Another possibility is for the customers to practice indirect usage towards the taxi industry, by pressuring the authorities to change the laws and regulations in the industry. A further possibility is that the customers gain more power and use their influence directly on the taxi industry (Frooman, 1999).

The opportunities to change the reality of the industry lie in the opportunity for the customer to act on their values. This can only happen if the facts and possibilities creating the reality of the taxi industry are changed through empowerment of the customers.

Near-future possibilities for the customers to gain more power lie in the emergence of substituting solutions. Carpooling is one substitute product that, through services like Go-More, has become more accessible. All over the world, the American Uber is gaining popularity, which could pressure the Danish taxi industry, if they succeed in entering the Danish market. Another possibility for empowering the customers is through the development of new technology. Apps can provide the consumers with more transparency in relation to prices and services. This could result in a need for change in the business model, in order for the taxi companies to capture the value from the new technology (Chesbrough \& Rosenbloom, 2002).

Our research focus has been how stakeholder theory can be used to explain why changes in the business model have not occurred. The academic literature describes that there are powerful barriers for business model innovation (Chesbrough, 2010). This implies that there could be other reasons for the lack of innovation than just the influence from stakeholders. One reason might be that dominant logic leads to companies only taking into account information that fits this logic (Chesbrough, 2010). Therefore, new business models often look unattractive to internal and external stakeholders on the outset (Johnson et al., 2008), which can explain why some companies might not be as willing to experiment with their business model in order to gain success from applying new technology (Chesbrough, 2010). Another explanation might be that business model innovation often leads to a need for organisational redesign, and mature organisations might be resistant towards making such a change.

\subsection{Contributions}

This paper contributes by giving an insight on the business model in the taxi industry. By applying the framework from Casadesus-Masanell \& Ricart (2010), we explain the business model of the industry, as well as the limited options for competing through business models and tactics. Furthermore, it contributes by showing how different stakeholders are influencing the business model and the possibility to make business model innovation (Frooman, 1999). The paper also contributes to the existing theory on the subject of business models. The research area of business models is still an underdeveloped field that lacks theoretical foundation (Schneider \& Spieth, 2013; Teece, 2010; Zott et al., 2011). We contribute by adding further knowledge to the subject. In current literature, there seems to be a lack of research that explores how business models evolve because of influence from different actors (Zott \& Amit, 2010). By using stakeholder theory, our research offers insights to how different actors can influence the business model of a company. Prior research on the subject of business model innovation identifies changes in the environment as a major driver for business model innovation (Chesbrough, 2010; Demil \& Lecocq, 2010; Schneider \& Spieth, 2013). Our research is not denying this, but we find that stakeholders can have a major influence on whether these changes will lead to business model innovation. Additionally, stakeholder theory was found to explain how different actors influence the business model of the taxi industry.

\subsection{Future research}

To further develop the understanding of how different stakeholders influence a company's business model, there is a need for extended research on the topic. There is a need to analyse if this theory have the same explanatory ability in other industries or companies, as have been the case in our study. This paper chose to observe the industry from an aggregated outside perspective. Further knowledge of how stakeholders influence business models could be gained by exploring deeper how the actors see their own role in the development of business models. This is the case for the taxi industry as well, as a further and deeper research with an inside perspective could contribute to a broader understanding of the industry. The reality used for the findings of this paper is based on the facts and possibilities available. Other researchers may get other facts and possibilities from their research, which leads to a different reality that may result in other findings. 


\section{Conclusion}

This paper illustrates the relationship between business model, business model innovation and stakeholder theory. We have conducted a study, based on the taxi industry, with a focus on how stakeholders can influence the business model and business model innovation of an industry. Our study concludes that it is possible to explain the lack of business model innovation in an industry, by the power and interest of the stakeholders. In our study, we found that the major stakeholders; the authorities and the taxi industry, have great influence on the business model and the possibility for business model innovation in the taxi industry. Even though there have been external factors that could lead to business model innovation, this did not happen, as it was not possible because of the stakeholders' influence. The rules and regulations, set up to protect the interests of the authorities, are restraining the tactical options of the individual taxi companies, which lowers the competition in the industry. 


\section{References}

Ackermann, F., \& Eden, C. (2011). Strategic management of stakeholders: Theory and practice. Long Range Planning, 44(3), 179-196.

Amit, R., \& Zott, C. (2012). Creating value through business model innovation. MIT Sloan Management Review, 53(3), 41.49.

Andersen, M. B. (2014). Taxi-app'en drivr tvunget ud af Aarhus. Retrieved from http://www.business.dk/transport/taxi-appen-drivr-tvunget-ud-af-aarhus

Bryson, J. M. (2004). What to do when stakeholders matter: Stakeholder identification and analysis techniques. Public Management Review, 6(1), 21-53.

Carayannis, E. G., Sindakis, S., \& Walter, C. (2015). Business model innovation as lever of organizational sustainability. The Journal of Technology Transfer, 40(1), 85-104.

Casadesus-Masanell, R., \& Ricart, J. E. (2010). From strategy to business models and onto tactics. Long Range Planning, 43(2/3), 195-215.

Casadesus-Masanell, R., \& Zhu, F. (2010). Strategies to fight ad-sponsored rivals. Management Science, 56(9), 14841499.

Chesbrough, H. (2010). Business model innovation: Opportunities and barriers. Long Range Planning, 43(2/3), 354363.

Chesbrough, H., \& Rosenbloom, R. S. (2002). The role of the business model in capturing value from innovation: Evidence from xerox corporation's technology spin-off companies. Industrial and Corporate Change, 11(3), 529-555.

Dalby, J., Lueg, R., Nielsen, L. S., Pedersen, L., \& Tomoni, A. C. 2014. National culture and business model change: a framework for successful expansions. Journal of Enterprising Culture, 22(4): 463-483.

Dansk Taxi Råd. (2010). På vej - analyse af det danske taximarked. Dansk Taxi Råd.

Demil, B., \& Lecocq, X. (2010). Business model evolution: In search of dynamic consistency. Long Range Planning, 43(2/3), 227-246.

Freeman, R. E. (1984). Strategic management: A stakeholder approach. New York, USA: Harpercollins College Div.

Friis, J. D., Lueg, R., Mayanja, R., Salling, S. T., \& Sørensen, K. A. M. 2015. Business model or strategy: which comes first? A lifecycle perspective in the Scandinavian software industry. Problems and Perspectives in Management, 13(2): 161-169.

Frooman, J. (1999). Stakeholder influence strategies. Academy of Management Review, 24(2), 191-205.

Haubro, A. P., Lomholt, H. A., Lueg, R., Nielsen, S. V., \& Knudsen., U. 2015. Tactical and strategic choices in business models: evidence from a Danish fashion outlet. Journal of Fashion Marketing and Management: forthcoming.

Jakobsen, M., Johansson I., \& Nørreklit, H. (2011). An Actors Approach to Management: Conceptual framework and company practices. Chap 2. Copenhagen, Denmark: DJOEF Publishing.

Johnson, M. W., Christensen, C. M., \& Kagermann, H. (2008). Reinventing your business model. Harvard Business School Press.

Konkurrencestyrelsen. (2008). Konkurrenceredegørelse 2008. Copenhagen, Denmark: Konkurrence- og Forbrugerstyrelsen.

Larsen, M. K., Lueg, R., Nissen, J. L., Schmaltz, C., \& Thorhauge, J. R. 2014. Can the business model of Handelsbanken be an archetype for small and medium sized banks? A comparative case study. Journal of Applied Business Research, 30(3): 869-882.

Lueg, K., Lueg, R., Andersen, K., \& Dancianu, V. 2016. Integrated reporting with CSR practices: a pragmatic constructivist case study in a Danish cultural setting. Corporate Communications: An International Journal, 21(1): 20-35.

Lueg, R., Clemmensen, S. N., \& Pedersen, M. M. 2015. The role of corporate sustainability in a low-cost business model - A case study in the Scandinavian fashion industry Business Strategy and the Environment, 24(5): 344-359.

Lueg, R., Malinauskaite, L., \& Marinova, I. 2014. The vital role of business processes for a business model: the case of a startup company. Problems and Perspectives in Management, 12(4): 213-220.

Lueg, R., Nedergaard, L., \& Svendgaard, S. 2013. The use of intellectual capital as a competitive tool: a Danish case study. International Journal of Management, 30(2): 217-231.

Magretta, J. (2002). Why business models matter. Harvard Business Review, 80(5), 86-92

Malmmose, M., Lueg, R., Khusainova, S., Iversen, P. S., \& Panti, S. B. 2014. Charging customers or making profit? Business model change in the software industry. Journal of Business Models, 2(1): 19-32. 
Mitchell, D., \& Coles, C. (2003). The ultimate competitive advantage of continuing business model innovation. Journal of Business Strategy, 24(5), 15-21.

Mitchell, R. K., Agle, B. R., \& Wood, D. J. (1997). Toward a theory of stakeholder identification and salience: Defining the principle of who and what really counts. Academy of Management Review, 22(4), 853-886.

Nielsen, C. E., \& Petersen, M. (2010). Taxiundersøgelse for fardselsstyrelsen. Copenhagen, Denmark: Færdselsstyrelsen.

Nørreklit, L., Nørreklit, H. \& Israelsen, P. (2006). The validity of management control topoi: Towards constructivist pragmatism. Management Accounting Research, 17, 42-71.

Osterwalder, A., Pigneur, Y., \& Tucci, C. L. (2005). Clarifying business models: Origins, present, and future of the concept. Communications of the Association for Information Systems, 16, 1-25.

Ryan, B., Scapens, R. W., \& Theobald, M. (2002). Research Method \& Methodology in Finance \& Accounting (2nd ed.). Hampshire, UK: South-Western Gengange Learning.

Scapens, R. W. (1990). Researching management accounting practice: The role of case study methods. British Accounting Review, 22(3), 259-281.

Schneider, S., \& Spieth, P. (2013). Business model innovation: Towards an integrated future research agenda. International Journal of Innovation Management, 17(1), 1-34.

Teece, D. J. (2010). Business models, business strategy and innovation. Long Range Planning, 43(2/3), $172-194$.

Transportministeriet. (2013). Betcenkning nr. 1542 fra udvalg om erhvervsmassig befordring i personbiler. Copenhagen, Denmark: Transportministeriet.

Yin, R. K. (2009). Case Study Research: Design and Methods (4th ed.). USA: Sage Publications, Inc.

Zott, C., \& Amit, R. (2010). Business model design: An activity system perspective. Long Range Planning, 43(2/3), 216-226.

Zott, C., Amit, R., \& Massa, L. (2011). The business model: Recent developments and future research. Journal of Management, 37(4), 1019-1042. 